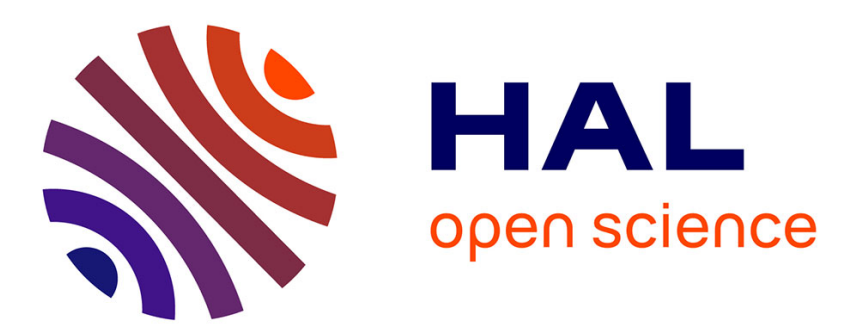

\title{
Response of breeding European Storm Petrels to habitat change
}

\author{
Bernard Cadiou, Frédéric Bioret, Delphine Chenesseau
}

\section{To cite this version:}

Bernard Cadiou, Frédéric Bioret, Delphine Chenesseau. Response of breeding European Storm Petrels to habitat change. Journal für Ornithologie = Journal of Ornithology, 2009, 151 (2), pp.317-327. 10.1007/s10336-009-0458-3 . hal-00568353

\section{HAL Id: hal-00568353 https://hal.science/hal-00568353}

Submitted on 23 Feb 2011

HAL is a multi-disciplinary open access archive for the deposit and dissemination of scientific research documents, whether they are published or not. The documents may come from teaching and research institutions in France or abroad, or from public or private research centers.
L'archive ouverte pluridisciplinaire HAL, est destinée au dépôt et à la diffusion de documents scientifiques de niveau recherche, publiés ou non, émanant des établissements d'enseignement et de recherche français ou étrangers, des laboratoires publics ou privés. 


\title{
Response of breeding European Storm Petrels Hydrobates pelagicus to habitat change
}

Bernard Cadiou - Fredéric Bioret - Delphine Chenesseau

\author{
B. Cadiou - D. Chenesseau \\ Bretagne Vivante - SEPNB, 186 rue Anatole France, BP 63121, F-29231 Brest \\ cedex 3, France \\ Tel. : +33 (0)298490718 \\ Fax : +33(0)298499580 \\ e-mail: bernard.cadiou@bretagne-vivante.org
}

Fredéric Bioret

Institut de Géoarchitecture, UFR Sciences et techniques, Université de Bretagne Occidentale, CS 93837, F-29238 Brest cedex 3, France 


\begin{abstract}
Mainly through trampling and manuring, ground-nesting seabirds induced significant habitat changes both on vegetation cover and soil in one of the largest French colonies of European Storm Petrel Hydrobates pelagicus, Habitat deterioration led to a high level of erosion and the collapse of many former Rabbit Oryctolagus cuniculus burrows previously occupied by breeding Storm Petrels. The loss of burrows accelerated in recent years since Great Cormorants Phalacrocorax carbo bred on the islet with growing numbers. The main consequence of this disturbance was at first shifting of breeding Storm Petrels from burrows to rocky sites, reflecting some behavioural plasticity to buffer environmental variability. But over eighteen years, a significant decrease in breeding numbers of Storm Petrels was recorded and attributed to continuous nest sites destruction. Thus, other behavioural responses were also suspected, such as temporary nonbreeding or emigration of birds which have to find a new nest site. Such a problem of heavy erosion and loss of nesting habitat could induce serious detrimental effects on burrowing seabirds breeding in a limited number of colonies.
\end{abstract}

\title{
Keywords
}

Hydrobates pelagicus; Nesting habitat; Burrow; Interspecific interactions;

Breeding numbers 


\section{Introduction}

Habitat deterioration is a serious threat to breeding seabirds (Burger and Gochfeld 1994; Jouventin 1994; del Hoyo et al. 1992; Probst et al. 2000; Baker et al. 2002). The most sensitive to such threats are species that breed underground, like many Procellariiformes or Alcids with about $80 \%$ (excluding Diomedeidae) and 77\% respectively using burrows or crevices (from del Hoyo et al. 1992, 1996). Modifications of their nesting habitat can either be due to a single factor or to a combination of different factors such as natural erosion, human impact or impact of other animals, endogenous or introduced species, directly through grazing, trampling or burrowing, or indirectly due to manuring (chemical impact of excrements) and modification of the vegetation cover. For example, Rabbits Oryctolagus cuniculus have had a significant detrimental impact on natural habitats ranging from Europe to Australia and New Zealand and on sub-Antarctic Islands (Norman 1970; Priddel et al. 2000; Baker et al. 2002; Courchamp et al. 2003). These impacts can be amplified on small islands where ecosystems tend to be more sensitive to perturbations (Gillham 1956b). Introduced cattle may also have a great impact on habitat through overgrazing, trampling or rooting (Warham 1990; Burger and Gochfeld 1994; Jouventin 1994; Zino et al. 2001; Baker et al. 2002; Carlile et al. 2003; Martínez-Gómez and Jacobsen 2004). It is not just introduced mammals that modify island habitats, impacts of indigenous species have also been reported, generally associated with an increase in numbers (shags on shearwaters: Richdale 1963; shags on petrels: Brothers 1984; seals on petrels: Berrow et al. 2000; gannets on shearwaters: Siorat 2004). Management and conservation programmes dedicated to some threatened seabird populations may require the active reduction of some impacts, e.g. removal of livestock, perhaps followed by habitat restoration that may also include the provision of artificial burrows (Warham 1996; Priddel et al. 2000; Carlile et al. 2003; Courchamp et al. 2003).

The European Storm Petrel Hydrobates pelagicus is the smallest breeding seabird in Europe and one of the smallest in the world (about $26 \mathrm{~g}$ ). The conservation status is considered as 'Secure' in Europe and 'Vulnerable' in France (Rocamora and Yeatman-Berthelot 1999; BirdLife International 2004). The nominate subspecies H. p. pelagicus breeds in the North-East Atlantic, from the Canary Islands to Norway and Iceland, and the subspecies H. p. melitensis is confined to the Mediterranean (Cramp and Simmons 1977; del Hoyo et al. 1992; Mitchell and Newton 2004). Due to the underground breeding habit of this small seabird and the consequential difficulties of census, the estimate of the world population is very approximate, ranging from 310000 to 690000 pairs (Mitchell and Newton 2004) and the population trend of the species still remains mainly unknown. European Storm Petrels nest in different habitats, cavities under rocks, boulders, dry stone walls or burrows generally initially excavated by other species, e.g. Rabbits or Manx Shearwaters Puffinus puffinus (Cramp and Simmons 1977). The numbers and distribution of the species are closely related to the availability of safe nesting sites, free of mammalian predators (de León et al. 2006). In Brittany (Western France), regular censuses have been carried out and European Storm Petrels breed at less than 20 colonies with a total estimate of nearly 900 pairs in 
2001-2002 and around 790 pairs in 2008, of which 82\% located in the Molène archipelago

(Cadiou 2002 and unpublished data).

In this study, we use long-term monitoring data collected over eighteen years on neighbouring breeding colonies of Storm Petrels to investigate the direct and indirect impacts of changes in their nesting habitat (especially burrows) caused by the colonisation and the activities of i) introduced Rabbits and ii) indigenous species of ground-nesting seabirds, both on vegetation and soil, and iii) also caused by a severe storm. We compare the results obtained for the state of vegetation cover and for the trend in breeding number of Storm Petrels and the nest site occupancy rate in colonies with different density of ground-nesting seabirds.

\section{Methods}

\section{Study site}

The study was conducted between 1991 and 2008 in the Iroise National Nature Reserve, and mainly focused on the islet of Roc'h Hir $\left(5^{\circ} 01^{\prime} \mathrm{N}, 48^{\circ} 25^{\prime} \mathrm{W}\right)$ which is one of six Storm Petrel colonies in the Molène archipelago (Brittany, W France). It is a low-lying islet (average height of $10 \mathrm{~m}$ ) around $200 \mathrm{~m}$ long and 40-70 m wide, with an area of 0.85 ha. Soil colonized by coastal vegetation is mainly located on the central part of the islet, with scattered boulders and rock piles covering the remainder (Fig. 1). Roc'h Hir is linked at low tide to the neighbouring islets of Enez Kreiz (0.39 ha) and Banneg (9.42 ha), where Storm Petrels also breed. Rabbits were very likely introduced to all three islets in the 1950s by local hunters (Cuillandre et al. 1989), but they had died-out by 1993 after a natural epidemic (probably VHD or myxomatosis). The three islets are also free of rats Rattus spp. and other mammals except for the Lesser White-toothed Shrew Crocidura suaveolens.

\section{Nest counts}

Census of Storm Petrels was mainly conducted by day during incubation and chick rearing, from late June to early September. Combinations of different methods were used for census of apparently occupied sites (AOS): direct investigation of nest chambers by hand or where possible by observation with a torch, or also, but only since 1999, by using the tape playback method (see Cadiou 2001 for details). AOS were identified by one or more indices recorded at different dates of visit during the breeding season: chick or down of chick, egg or egg shells, apparently incubating adult, non-incubating adult, adult responding to tape playback. It was sometime difficult to assess if the egg or egg shells, especially when inaccessible, was laid during the current breeding season or during the previous one. Thus in some years, there were a minimum and a maximum number of AOS according to this uncertainty. All old chicks which could be caught in nest sites were ringed as well as a few adults, and subsequent controls in nest sites in the different study colonies gave the opportunity to assess breeding and natal dispersal. Annual censuses were conducted since 1991, excepted in 1993 and 1995-1996. Each breeding site was numbered and mapped, by painting the number on a neighbouring rock or on a small stone placed near the 
entrance. Individual marking of nest sites allowed monitoring their occupancy from year to year. Initiated in 1991, nest marking was not done between 1992 and 1997, and a few previously known nest sites could not subsequently be relocated due to weathering of the paint. During census visits, all previously known nest sites as well as all potential breeding sites were inspected and newly occupied sites were discovered each year. Nest sites permanently destroyed or with the entrance filled up were recorded as 'dead sites'. The cumulative number of dead sites was used as a measure of nest site destruction. In a few cases, the entrance of a burrow was blocked in one year and naturally opened again in the following year. A total of 241 different nest sites have been occupied at least once since 1991, including eight sites that were not relocated and considered as being probably dead sites. To take in account uncertainty about these sites, we added $4 \pm 4$ sites to the number of dead sites recorded annually from 1997 to 2008. The number of potentially available sites corresponded to the number of sites known to have been occupied at least once during the study period, opened in the current breeding season and considered as useable for Storm Petrels, out of which some of them were effectively occupied (i.e. AOS; total number of known sites $=$ AOS + unoccupied potentially available sites + dead sites). For Great Cormorants, European Shags and gulls, well-built nests (empty or containing eggs or chicks) were counted during the peak of incubation period from March to May according to the species. Over the 18 years of the study period, nest counts were available for 15 years for Storm-petrels and Shags, for 12 years for Cormorants (established since 1997), but only for five years for gulls. Two main areas, South and North, were distinguished on the islet according to topographical features and to the distribution of Storm Petrels and Great Cormorants (Fig. 1).

\section{Types of Storm Petrel nest sites}

Physical characteristics of nest sites were mainly recorded in 1991 and 2002 with some additional data from other years. Three main different types of sites can be distinguished: i) rocky sites (RS), natural cavities or crevices under boulders or in rocky cracks, ii) Rabbit burrows under boulders (BB), a partially buried block being the roof of the site, and iii) Rabbit burrows in the soil (BS), in bare earth or covered with vegetation. This last category is the most sensitive to trampling and erosion.

\section{Artificial burrows}

Due to the damage recorded on burrows, an experimental study was conducted within the framework of a LIFE nature project 'marine islets and archipelagos in Brittany'. In March 1999, 41 artificial burrows (AB) were provided in the north-eastern part of the islet (Fig. 1): three previously known nest sites with a threat of collapse, five previously known nest sites already collapsed and 33 new nest sites. All the previously known sites were burrows in the soil (BS). The new holes were dug in the soil before the insertion of a drainage plastic pipe $(50 \mathrm{~cm}$ long and 10 $\mathrm{cm}$ diameter), constituting both the tunnel and the nest chamber. A partial cut was made in the floor part to avoid egg laying directly on the plastic (Warham 1996). 


\section{Vegetation surveys}

Vegetation surveys were conducted in order to assess long term floristic changes and vegetation dynamic processes, which can affect the breeding habitat of Storm Petrels, especially burrows, through impact on soil stability and erosion. Following the sigmatist phytosociological methodology (Géhu and Rivas-Martinez 1981, Géhu 1986), exhaustive lists of plants were recorded on homogeneous areas distinguished on the basis of floristical, physiognomical and ecological characteristics and a dominance-abundance score was assigned to each species. Data collected on Roc'h Hir (1986 and 2003, 3 and 13 sample plots respectively, with a surface ranging from 3 to $50 \mathrm{~m}^{2}$ ) were compared with surveys set up on similar plant communities on the neighbouring island of Banneg (1986 and 1998, 3 and 6 samples respectively, from 10 to $100 \mathrm{~m}^{2}$ ) as well as on Ouessant, an inhabited isle with an area of 1558 ha located a few kilometres apart (1986, 8 samples of $100 \mathrm{~m}^{2}$, without seabird colonies) (Bioret 1989 and unpublished data).

\section{Statistical analyses}

The relation between number of dead sites, and AOS, and number of ground-nesting seabirds was analysed using generalised linear model (GLM) of regression. Initial model considered the simultaneous effects of number of ground-nesting seabirds, number of dead sites, year and their interactions on the number of AOS. Due to the lack of regular counts for gulls, there was not enough data to fit the model with the simultaneous effects of all the ground-species, excepted for Cormorants and Shags. In order to compare the spatial and temporal trend in AOS distribution between the two Storm Petrel areas or between the four different categories of nest sites, we calculated annual relative values (number of AOS in each area or for each category of sites divided by the total number of AOS recorded that year). Ratios were arcsine transformed before using generalised linear model (GLM) of regression with year as the covariate and area or category of nest sites as a factor. Initial model considered the simultaneous effects of area, type of site, year and their interactions on the AOS distribution. The $P$-value was set at 0.05 and the Bonferroni correction was applied where separate linear regression analyses were performed on data sub-sets for the four different type of sites, the significance level being then 0.0125 for each test performed. We also used a Chi-square test to compare the number of AOS versus empty available sites between the two neighbouring colonies of Roc'h Hir and Enez Kreiz.

\section{Results}

\section{State of the vegetation cover}

Four successive stages characterized the vegetation dynamic process (Table 1). The original unaffected vegetation, the historical climax, consists of a dense maritime grassland community dominated by perennial halophytes (Table 1). This state, recorded on the nearby inhabited isle of Ouessant, was supposed to exist on the islets up to the 1970s (J.-Y. Monnat, personal communication). The following stage, the biotic climax, corresponds to an Armeria maritima 
cushion grassland, a vegetation facies directly linked to Rabbit overgrazing (Table 1). Subsequently, increasing gull and Rabbit pressure leads to a high level of vegetation disturbance and to the development of a secondary community, totally different and dominated by halonitrophilous species (Table 1). The species richness was divided by two, original species vanished or still remain as relicts. The rapid decrease of gull populations since the end of the 1980s (Cadiou and Yésou 2006) and the natural extinction of Rabbits in 1993 have led to a recovery process on Banneg towards a fourth stage, the local climax. It is a dense herbaceous grassland corresponding to an impoverished vegetation facies without a set of characteristic species which did not recover (Table 1; Kruskal Wallis test on species richness, $H=21.053, P<0.001$ ). However, due to high density of ground-nesting seabirds, this stage was never reached on Roc'h Hir where the secondary community was mainly dominated by Beta and Atriplex, and locally by Cochlearia. This Cochlearia community, dominated by non perennial species, does not present a total coverage, especially in wintertime when large bare soil zones are visible and exposed to erosion. On Enez Kreiz, the secondary community was less damaged without large bare areas exposed to erosion.

\section{Impact of the storm in 2008}

A storm occurred in early March 2008 and submerging waves washed out all nests of Cormorants on the islet, with subsequent replacement laying in April. Some rocks were also moved, destroying 10 sites of Storm Petrels, mainly located in the South (6 rocky sites, 3 burrows under blocks and 1 burrow in soil). New favourable nesting habitat was also created by the storm and two pairs of Storm Petrels were found a few months later in a new rock pile accumulated on the South-East coast.

\section{Numbers and distribution of ground-nesting seabirds}

Cormorants successfully bred annually on Roc'h Hir since 1997 with increasing numbers and a maximum of 132 nests in 2007 (Fig. 2). The small decline in their breeding numbers between 2007 and 2008 was probably linked to the storm. The distribution of nests showed marked interannual variability: at first, birds mainly occupied rocky areas and afterwards they settled elsewhere, at the base and on the top of the rocky outcrop since 2004 and in the central part of the southern area in 2008. On the whole, they nested at least once about every where in the South of the islet.

Movements of walking Cormorants were always towards the East coast, less exposed to waves, sometimes creating large routes in the vegetation due to trampling (Fig. 1).

Shags steadily increased from one breeding pair in 1982 to 84 in 2004. Most of the Shags initially nested on the rocky outcrop and in the southern part of the islet, with the remaining pairs scattered under blocks over the islet. However, many of the pairs on the rocky outcrop seems to have been displaced by Cormorants in 2005 and only 29 nests were recorded on the islet. Numbers increased afterwards and there were 41 nests in 2008.

Great Black-backed Gulls were relatively stable in recent years (e.g. 66 breeding pairs in 1992 and 72 in 2004 but only 40 in 2007) and more or less homogeneously distributed, avoiding the areas 
occupied by Cormorants and Shags. Only a few pairs of Herring and Lesser Black-backed Gulls also bred.

\section{Numbers and distribution of Storm Petrels}

The first estimate of the breeding population on the islet was 47 AOS counted in 1969 (Brien 1970). In the 1970s and the 1980s data are too sketchy to know the trend in breeding numbers.

Over the study period, the annual number of AOS increased and culminated in 2000 but decreased significantly afterwards (Fig. 2; quadratic regression: $F_{2,12}=8.98, P<0.01, R^{2}=0.53$ ).

The cumulative number of dead sites significantly increased over the study period, from 0-1 in 1991 to $138-146$ in 2008 (Fig. $2 ; F_{1,13}=96.27, P<0.001, R^{2}=0.88$ ). There was a highly significant linear relationship between the cumulative number of dead sites and the breeding numbers of Cormorants $\left(F_{1,13}=220.63, P<0.001, R^{2}=0.94\right)$, but no linear relationship with the number of Shags or gulls (respectively $F_{1,10}=1.56$, n.s. and $F_{1,2}=1.66$, n.s.). From 1997 to 2008 , 26-27 cases of nest sites occupied by breeding Storm Petrels in year $\mathrm{t}$ and collapsed in year $\mathrm{t}+1$ were recorded: 1 in 1997-1998, 0-1 in 1998-1999 (with uncertainty on the breeding status in 1998), none in 1999-2000, 3 in 2000-2001, 2 in 2001-2002, 1 in 2002-2003, 4 in 2003-2004, 8 in 2004-2005, none in 2005-2006, 4 in 2006-2007 and 3 in 2007-2008. On the other hand, from 1999 to 2008, 11 different artificial burrows were used at least once: 1 previously known site with a threat of collapse, 1 previously known site already collapsed and 9 new sites. Two of these artificial sites were occupied five times over the study period, the others mostly once or twice. Analyses pointed out a major significant negative relationship between the annual number of AOS and the cumulative number of dead sites, and also a significant effect of year without any effect of their interaction, but no effect of the number of Cormorants (final model of the GLM analysis: number of dead sites, $\mathrm{df}=1, F=15.31, \mathrm{P}<0.01$; year, $\mathrm{df}=1, F=7.36, \mathrm{P}<0.05$; Fig. 2). Initial model for this same analysis but including also the number of Shags was not significant $\left(F_{10,1}=\right.$ 4.74 , n.s.).

There were major effects of type of site and interaction between type of site and year on the spatial and temporal variation in AOS distribution, and a less pronounced effect of area (final model of the GLM analysis: area, $\mathrm{df}=1, F=5.25, \mathrm{P}<0.05$; type of site, $\mathrm{df}=3, F=28.82,<0.001$; year, $\mathrm{df}$ $=1, F=0.02$, n.s.; type of site $*$ year, $\mathrm{df}=3, F=28.79, \mathrm{P}<<0.001)$. At the scale of the relative proportion of AOS, separated linear regression analyses indicated that the relative proportion of burrows in soil amongst AOS registered a significant continuous decline from 74\% in 1991 to $11 \%$ in 2008 (Fig. $3 \mathrm{a} ; F_{1,13}=86.41, P<0.001, R^{2}=0.87$ ). Over the same period, the relative proportion of AOS for rocky sites increased from $16 \%$ to $76 \%$ (Fig. $3 \mathrm{a} ; F_{1,13}=33.15, P<0.001$, $R^{2}=0.72$ ) and there was no significant trend for burrows under blocks and artificial burrows (Fig. 3a; respectively $F_{1,13}=3.50$, n.s. and $F_{1,8}=0.04$, n.s.). As a consequence of habitat degradation, the relative distribution of AOS amongst the different types of sites has undergone major changes from 1991 to 2008. The variation in relative proportion of AOS between the two areas showed marked interannual variability and, when analysed separately, there was no significant trend (Fig. $3 \mathrm{~b} ; F_{3,26}=2.66$, n.s.). 
Burrows in soil were the more numerous known sites (55\%), followed by rocky sites (33\%), burrows under blocks (9\%) and artificial burrows (4\%; Fig. 4a). The rate of nest site destruction was significantly different amongst these categories and the two areas $\left(\chi^{2}{ }_{2}=68.25, P<0.001\right.$ and $\chi_{1}^{2}=4.84$, with Yates' correction, $P<0.05$ respectively; dead sites versus potentially available sites, without taking in account the 9 new artificial burrows ABn; Fig. 4b). About $60 \%$ of the nest sites have been destroyed since 1991, the respective proportions being two third in the South and one half in the North. Burrows in soil represented the largest proportion of dead sites ( $82 \%$ of the known sites for this category and $76 \%$ of the total of dead sites; Fig. 4b). For burrows under blocks, $62 \%$ have been destroyed, representing $9 \%$ of the total of dead sites. These proportions for rocky sites were $25 \%$ and $14 \%$ respectively.

The South of the islet is the area the most impacted by Cormorants, with also additional effects of gulls. The impact of Shags appeared to be limited, except around the rocky outcrop. In the North, the destruction of burrows was mainly due to the impact of gulls. It would seem that the expansion of Cormorants in the South in recent years have forced some Great Black-backed Gulls to move to the North. The North end still remains the only area that has not suffered from erosion or become overgrown with tall vegetation. Most of the AOS were now rocky sites located at the South and North ends of the islet as well as around the rocky outcrop, and most of the sites newly occupied in recent years were rocky sites.

The proportion of unused potentially available nest sites on Roc'h Hir ranged between $60 \%$ and $69 \%$ in 2005-2008. The corresponding non-occupancy rate was $46 \%$ to $62 \%$ on Enez Kreiz with about 112 AOS in 2008 and only 6 dead sites out of 216 known nest sites, mainly old Rabbit burrows (comparison between these two colonies, number of AOS versus empty available sites in 2008: $\chi_{1}^{2}=5.10$, with Yates' correction, $\left.P<0.05\right)$.

\section{Discussion}

\section{Impact of seabirds and Rabbits on vegetation and soil}

Through different actions, such as trampling and manuring, large seabird colonies induce significant changes of chemicals properties of the soil and of plant cover (Ellis 2005), as recorded in gull and some petrel colonies for example (Gillham 1956a, b; Bioret et al. 1988, 1991; Warham 1996; Vidal et al. 1998; García et al. 2002). These various effects lead to the progressive replacement of original plant species by secondary communities with a dominance of annual species, and also to a gradual soil denudation of some impacted areas (Gillham 1956a; Bioret et al. 1988, 1991; Vidal et al. 1998; see review in Ellis 2005; Fig. 5). After denudation, soil became directly exposed to leaching and increasing erosion, especially in winter. The damage can be irreversible with a complete disappearance of the soil, uncovering the bedrock. Moreover, in areas where plant cover has been reduced, Storm Petrel burrows remaining in a shallow soil thus became increasingly vulnerable to trampling by ground-nesting seabirds and to the risk of blocking. Hornung (1981) has shown that infilling of burrow entrances on an Atlantic Puffin Fratercula arctica colony outside the breeding season was higher in bare and sparsely vegetated ground. 
Bancroft et al. (2005) recorded a rate of collapse of burrow entrances in Wedge-tailed Shearwater Puffinus pacificus twice higher in areas with shallow-rooted annual vegetation cover than in areas with perennial species. Norman (1970), when studying the effects of Rabbits on Short-tailed Shearwaters Puffinus tenuirostris, concluded that destruction of vegetation increased erosion and impacted areas became unfavourable for burrowing birds. Tollu (1984) reported a special case where the own activity of Flesh-footed Shearwaters Puffinus carneipes have led to erosion and complete disappearance of the area where birds initially bred.

As Rabbits, which initially excavated all the burrows on Roc'h Hir, have permanently disappeared, rocky sites would be the most numerous remaining available nest sites in the future with some burrows under boulders and artificial burrows. The burrowing activity of introduced Rabbits has initially clearly increased the number of available nest sites for Storm Petrels but Rabbits have also contributed to increase the instability of the shallow and friable soil, before intensification of trampling by expanding ground-nesting seabirds, firstly gulls, then Shags and finally Cormorants, with an additional effect of the storm in 2008. Storm Petrels apparently did not try to reopen collapsed burrows, despite some observers claiming they are capable of doing so (Cramp and Simmons 1977; del Hoyo et al. 1992; Bancroft et al. 2005). The fragility of the soil in some areas on the islet implies that observers should walk very carefully to avoid accidental trampling and additional destruction of burrows.

The rapid increase of Cormorants on Roc'h Hir, associated with regular changes in distribution of their nests, has accelerated the erosion process initially started with the presence of Rabbits and gulls. A Great Cormorant has potentially a greater impact because it weighs about twice as much as a Great Black-backed Gull (very approximately 3 and $1.5 \mathrm{~kg}$ ), it walks more than gulls, nests in higher density, has more young and produces far more guano around the nest. This explains the rapid increasing rate of burrow collapse in the South of the islet where breeding Cormorants were established.

\section{Responses of Storm Petrels to habitat change}

The continuous decrease on Roc'h Hir since 2000 differed from the demographic trend recorded on the neighbouring colonies over the same period, with increasing breeding numbers. Estimate for the whole Molène archipelago was about $200 \mathrm{AOS}$ at the end of the 1980s and culminated at 750 AOS in 2001-2002 but decreased afterwards annually to only 480 in 2007 and was 650 in 2008 after a new increase (Cadiou 2002 and unpublished data). Reasons of overall decrease remained unknown but could be linked to availability of food resources and non-breeding (Hémery et al. 1986), as well as reduction of survival probabilities. The fate of the colony on Roc'h Hir especially markedly contrasted with the one of the small nearby islet of Enez Kreiz, where most of the breeding sites were old Rabbit burrows but where the density of ground-nesting seabirds was much lower, with only 2-5 pairs of Shags and 6-8 pairs of Great Black-backed Gulls breeding annually. The vegetation cover and the soil were in better conservation state, minimizing the risk of burrow collapse. Thus, the presence and impact of Cormorants, and to a lesser extent gulls and Shags, appears as the main difference between these two nearby colonies. A difference in adult survival between these colonies seemed unconvincing to explain the differences in population 
trends. Nevertheless, it should be underlined that important differences in demographic parameters (such as survival and breeding success) could be detected between neighbouring Storm Petrel colonies (Tavecchia et al. 2008).

Pairs of Storm Petrels that were unable to reoccupy their nest site from one year to the next due to collapse were be forced to disperse elsewhere on the islet or to neighbouring colonies. At first, breeding Storm Petrels can buffer the changes in nesting habitat by shifting from destroyed burrows to rocky sites, resulting in a modification of the spatial distribution of AOS over the islet. Some disturbed pairs can then settle and breed together close to their former site. But, as a progressive and continuous decrease in breeding numbers was recorded over years, and exclusively on Roc'h Hir, other types of behavioural responses should be considered for these Storm Petrels which have to find a new nest site. Temporary non-breeding or emigration were suspected and such behaviours could be costly for the birds as this could induce some nonbreeding years or a potential decline in breeding success during their future breeding attempt due to burrow and partner change (Brooke 1990; Wharham 1990; Mougin 1991; Bried and Jouventin 2002). Procellariiformes, as many other seabird species, are generally considered to be faithful to their nest site and their partner, at least as long as they breed successfully, and pair bond is assumed to be linked to site fidelity (Richdale 1963; Morse and Buchheister 1979; Morse and Kress 1984; Wharham 1990; Bried and Jouventin 2002). Moreover, the behavioural process governing the acquisition of a site and a partner generally takes some years (Danchin et al. 1991; Warham 1996; Bried and Jouventin 2002). The regular collapse of nest sites on Roc'h Hir forced breeders to search for and occupy new sites on the islet more and more frequently that probably result in pair bond disruption and in some birds skipping breeding during one or more years. From our data, it can be assumed that Storm Petrels settled at first preferentially in burrows, and were forced to occupy rocky sites when the number of available burrows declined due to nest destruction. We have no data on the breeding success in the different types of sites, but if there was a significant difference with higher failure rate in rocky sites the increased proportion of birds using such sites may have large implications for productivity of the colony as a whole. Over the long term, Storm Petrels would emigrate if the number of available nest sites will be too low due to continuous nest destruction. Indeed, exceptional events like the disappearance of their previous site can force seabirds to emigrate to another colony (Richdale 1963; Morse and Kress 1984). Richdale (1963) have shown that changes of sites in the Sooty Shearwater Puffinus griseus occurred at an average distance of $2.3 \mathrm{~m}$ in normal situation but this distance increased to $12.2 \mathrm{~m}$ after installation of Bronze and Stewart Island Shags Phalacrocorax chalconotus and P. huttoni in one part of the colony, preventing occupation of breeding sites by shearwaters. Temporary nonbreeding and breeding dispersal were also recorded in the Black-legged Kittiwake Rissa tridactyla after the destruction of the warehouse where they previously bred (Fairweather and Coulson 1995). In the present study, nesting habitat change on Roc'h Hir seems not to constitute a major threat for Storm Petrels because there are numerous available nest sites in the two nearby colonies. For more or less isolated small colonies such a problem of erosion could induce much more serious detrimental effects if available nest sites would be definitely destroyed. Indeed, by maintaining the maximum number of colonies the probability of extinction of the metapopulation 
decreases (Hanski and Gilpin 1997). Habitat destruction was also reported on some Storm Petrel colonies in Britain and Ireland. On Auskerry, the largest colony in Orkney, a 79\% decline in breeding numbers between 1995 and 2001 was mainly attributed to the destruction of old Rabbit burrows by increasing Sheep Ovis aries pressure (Mitchell and Newton 2004). However, lack of data from neighbouring colonies meant it was unclear what effect the emigration from Auskerry had on numbers breeding in the region as a whole. And it should be noted that breeding and natal dispersal still remain poorly investigated behaviours in European Storm Petrel. Emigration of breeders from Roc'h Hir to the very close islets of Enez Kreiz or Banneg (see Fig. 1) does not appear theoretically improbable even if a previous study pointed out an absence of exchange between two Storm Petrel colonies located $1.3 \mathrm{~km}$ apart (Hémery et al. 1986). Unfortunately, breeders have not been regularly ringed on Roc'h Hir and eventual subsequent movements (i.e. breeding dispersal) will be difficult to identify (no case recorded during the study period), excepted for birds ringed there as chicks that could emigrate to the neighbouring colonies and could be controlled as breeders in the future, as illustrated by the two cases of natal dispersal already recorded (out of three cases of natal dispersal recorded amongst 47 birds ringed as chicks and controlled as breeders in one of the three study colonies; own data).

\section{Artificial nest sites for burrowing seabirds}

Up to now, adding new artificial nest sites is not planned on Roc'h Hir, especially due to the availability of breeding habitat in the two neighbouring colonies and also to their relatively low occupancy rate, and such experiments has to be in accordance with the management plan of the Nature Reserve. Provisioning artificial burrows has been used in seabird conservation and restoration programmes throughout the last few decades, for petrels (Byrd 1979; Podolsky and Kress 1989; Priddel and Carlile 1995; Cruz and Cruz 1996; Warham 1996; Carlile et al. 2003; de León and Mínguez 2003, Bolton et al. 2004; Miskelly and Taylor 2004), auklets (Thayer et al. 2000) or penguins (Houston 1999). Artificial sites could be considered as a useful conservation tool to limit the effects of heavy soil erosion or to increase the number of potential nest sites (Priddel and Carlile 1995).

\section{Conclusions}

Results pointed out that cumulative impacts of perturbations induced by Rabbits and groundnesting seabirds on an islet with shallow and friable soil have led over a period of eighteen years to clear changes in vegetation, to habitat degradation and to a rapid increase in the collapse of burrows used by Storm Petrels. Amongst all the interspecific interactions identified, it should be emphasized that the recent and rapid increase of Cormorants has had the major negative impact, also intensified by a storm in 2008. Storm Petrel behavioural plasticity to buffer such environmental variability can result in a change of nest site in the same colony. But, as breeding numbers have undergone a decrease at the scale of this impacted colony, emigration to another colony or temporary non-breeding could also be suspected. Long-term monitoring of seabirds and vegetation should be maintained in the future and could provide information about numerical 
trends, breeding success in the different types of nest sites, adult survival, dispersal between colonies and dynamic processes of the soil-vegetation system.

\section{Zusammenfassung}

\section{Reaktion brütender Sturmschwalben (Hydrobates pelagicus) auf Habitatveränderungen}

Bodenbrütende Seevögel haben, vor allem durch Trampeln und Düngung, erhebliche Habitatveränderungen in Vegetationsbedeckung und Boden in einer der größten Brutkolonie Französischer Sturmschwalben verursacht. Habitatverfall führte zu starker Erosion und zum Einbruch vieler ehemaliger Kaninchenbauten (Oryctolagus cuniculus), die vorher von Sturmschwalben als Bruthöhlen genutzt wurden. Seit Kormorane (Phalacrocorax carbo) in zunehmender Anzahl auf der Insel brüten, beschleunigte sich der Verlust der Höhlen in den letzten Jahren. Auf diese Störung hin verlagerten die Sturmschwalben zunächst ihre Nistplätze von Bruthöhlen weg hin zu felsigem Gelände. Dies zeigt dass ein gewisser Grad an Verhaltensplastizität zum Abdämpfen von variablen Umweltbedingungen vorhanden ist. Jedoch nahm die Anzahl der Brutvögel über achtzehn Jahre hinweg signifikant $\mathrm{ab}$, was der andauernden Zerstörung von Nistplätzen zugeschrieben wurde. Auch wurde vermutet, dass einige Vögel auf die Nistplatzknappheit reagierten, indem sie temporär nicht brüteten oder emigrierten. Für in Höhlen brütende Seevögel, deren Anzahl an Brutkolonien limitiert ist, kann ein solches Problem, ausgelöst durch starke Erosion und Bruthabitatverlust, erhebliche, negative Auswirkungen haben.

\section{Acknowledgments}

The study was conducted on the Iroise National Nature Reserve, managed by the NGO Bretagne Vivante-SEPNB with financial support of the Conseil Général du Finistère, property owner of the reserve, and the Direction Régionale de l'Environnement (DIREN Bretagne; French ministry of environment). The study was funded by the Conseil Régional de Bretagne (Nature Contracts 'breeding seabirds in Brittany'), by the Conseil Général du Finistère and by the EC Life Project 'marine archipelagos and islets in Brittany' (ref. LIFE Nature B4-3200/98/470). 
We are very grateful to Jean-Yves Le Gall and David Bourles, wardens of the Nature Reserve, as well as to the volunteers helping for fieldwork, to the previous observers for collecting data on seabirds since the 1960s, especially Jean-Yves Monnat and Jean-Pierre Cuillandre for their work on Storm Petrels, to Eric Vidal and Ian Mitchell for providing helpful comments on earlier draft of the manuscript and to the latter for checking the English, and also to two anonymous referees who reviewed our manuscript and provided constructive criticism. 


\section{References}

Baker GB, Gales R, Hamilton S, Wilkinson V (2002) Albatrosses and petrels in Australia: a review of their conservation and management. Emu 102:71-97

Bancroft WJ, Roberts JD, Garkaklis MJ (2005) Burrow entrance attrition rate in Wedge-tailed Shearwater Puffinus pacificus colonies on Rottnest Island, Western Australia. Mar Ornithol 33:2326

Berrow SD, Croxall JP, Grant SD (2000) Status of White-chinned Petrels Procellaria aequinoctialis Linaeus 1758, at Bird Island, South Georgia. Antarct Sci 12: 399-405

Bioret F (1989) Contribution à l'étude de la flore et de la végétation de quelques îles et archipels ouest et sud armoricains. Doctoral thesis, University of Nantes, Nantes, France

Bioret F, Bouzillé J-B, Godeau M (1988) Exemples de gradients de transformation de la végétation de quelques îlots de deux archipels armoricains. Influence de zoopopulations. In: Géhu J-M (ed) Phytosociologie et conservation de la nature, Strasbourg 1987, Colloques

Phytosociologiques, Vol. XV, Gebr. Borntraeger Verlagsbuchhandlung, Stuttgart, pp 509-531

Bioret F, Cuillandre J-P, Fichaut B (1991) Degeneration processes of a microinsular ecosystem put through gulls influence: the isle of Banneg (Finistère, France). Essay of ecological integrated cartography. In: Ravera $\mathrm{O}$ (ed) Terrestrial and aquatic ecosystems: perturbation and recovery, Ellis Horwood Ltd, New York, pp 276-283

BirdLife International (2004) Birds in Europe. Population estimates, trends and conservation status. BirdLife Conservation Series no. 12, BirdLife International, Cambridge

Bolton M, Medeiros R, Hothersall B, Campos A (2004) The use of artificial breeding chambers as a conservation measure for cavity-nesting Procellariiform seabirds: a case study of the Madeiran Storm Petrel (Oceanodroma castro). Biol Conserv 116:73-80

Bried J, Jouventin P (2002) Site and mate choice in seabirds: an evolutionary approach. In: Schreiber EA, Burger J (eds) Biology of marine birds, CRC Press, Boca Raton, Florida, pp 263 305

Brien Y (1970) Statut actuel des oiseaux marins nicheurs en Bretagne. VIII. Mise au point en 1970 : visites récentes et état actuel des effectifs par localité. Ar Vran 3:167-275

Brooke M (1990) The Manx Shearwater. Poyser, London

Brothers NP (1984) Breeding, distribution and status of burrow-nesting petrels at Macquarie island. Aust Wildl Res 11:113-131

Burger J, Gochfeld M (1994) Predation and effects of humans on island-nesting seabirds. In: Nettleship DN, Burger J, Gochfeld M (eds) Seabirds on islands. Threats, case studies and action plans, BirdLife Conservation Series no. 1, BirdLife International, Cambridge, pp 39-67

Byrd GV (1979) Artificial nest structures used by Wedge-tailed Shearwaters at Kilauea Point, Kauai. Elepaio 40:10-12

Cadiou B (2001) The breeding biology of the European Storm-Petrel Hydrobates pelagicus in Brittany, France. Atl Seabirds 3:149-164

Cadiou B (2002) Oiseaux marins nicheurs de Bretagne. Les cahiers naturalistes de Bretagne $\mathrm{N}^{\circ} 4$, Conseil Régional de Bretagne, Éditions Biotope, Mèze 
Cadiou B, Yésou P (2006) Évolution des populations de Goélands bruns, argentés et marins Larus fuscus, L. argentatus, L. marinus dans l'archipel de Molène (Bretagne, France) : bilan de 50 ans de suivi des colonies. Rev Écol-Terre Vie 61:159-173

Carlile N, Priddel D, Zino F, Natividad C, Wingate DB (2003) A review of four successful recovery programmes for threatened sub-tropical petrels. Mar Ornithol 31:185-192

Courchamp F, Chapuis J-L, Pascal M (2003) Mammal invaders on islands: impact, control and control impact. Biol Rev 78:347-383

Cramp S, Simons KEL (eds, 1977) Handbook of the birds of the Western Palearctic, Vol. 1. Ostrich to Ducks. Oxford University Press, Oxford

Cruz JB, Cruz F (1996) Conservation of the Dark-rumped Petrel Pterodroma phaeopygia of the Galápagos Islands, 1982-1991. Bird Conserv Int 6:23-32

Cuillandre J-P, Bargain B, Bioret F, Fichaut B, Hamon J, Henry J (1989) Le Pétrel tempête à Banneg. Première partie: évolution de la colonie entre 1968 et 1989, impact de la prédation par les laridés. Penn ar Bed 135:19-33

Danchin E, Cadiou B, Monnat J-Y, Rodriguez Estrella R (1991) Recruitment in long-lived birds: conceptual framework and behavioural mechanisms. Proc Int Ornithol Congr 20:1641-1656 de León A, Mínguez E (2003) Occupancy rates and nesting success of European Storm-Petrels breeding inside artificial nest-boxes. Sci Mar 67:109-112

de León A, Mínguez E, Harvey P, Meek E, Crane JE, Furness RW (2006) Factors affecting breeding distribution of Storm-petrels Hydrobates pelagicus in Orkney and Shetland. Bird Study 53:64-72

del Hoyo J, Elliott A, Sargatal J (eds, 1992) Handbook of the birds of the world, Vol. 1. Ostrich to Ducks. Lynx Edicions, Barcelona

del Hoyo J, Elliott A, Sargatal J (eds, 1996) Handbook of the birds of the world, Vol. 3. Hoatzin to Auks. Lynx Edicions, Barcelona

Ellis JC (2005) Marine birds on land: a review of plant biomass, species richness, and community composition in seabird colonies. Plant Ecol 181:227-241

Fairweather JA, Coulson JC (1995) The influence of forced site change on the dispersal and breeding of the Black-legged Kittiwake Rissa tridactyla. Col Waterbirds 18:30-40

García LV, Marañón T, Ojeda F, Clemente L, Redondo R (2002) Seagull influence on soil properties, chenopod shrub distribution, and leaf nutrient status in semi-arid Mediterranean islands. Oikos 98:75-86

Géhu J-M (1986) Des complexes de groupements végétaux à la phytosociologie paysagère contemporaine. Inform Bot Ital 18:53-83

Géhu J-M, Rivas-Martinez S (1981) Notions fondamentales de phytosociologie. In: Dierschke H (ed) Syntaxonomie, Berichte der Internationalen Symposien der Internationalen Vereinigung für Vegetationskunde (Rinteln 1980), Cramer, Vaduz, pp 5-33

Gillham ME (1956a) Ecology of the Pembrokeshire Islands. IV. Effects of treading and burrowing by birds and mammals. J Ecol 44:51-82

Gillham ME (1956b) Ecology of the Pembrokeshire Islands. V. Manuring by the colonial seabirds and mammals, with a note on seed distribution by gulls. J Ecol 44:429-454 
Hémery G, d'Elbée E, Terrasse JF (1986) Régulation d'une population de Pétrels-tempête Hydrobates pelagicus par reproduction intermittente. CR Acad Sci Ser III 9:353-356

Hanski I, Gilpin ME (1997) Metapopulation biology: ecology, genetics and evolution. Academic Press, San Diego.

Hornung M (1981) Burrow excavation and infill in the Farne Islands Puffin colony. Trans Nat Hist Soc Northumbr 43:45-54

Houston DM (1999) The use of nest boxes for Blue Penguins (Eudyptula minor). Ecol Manag 7:711

Jouventin P (1994) Past, present and future of Amsterdam Island (Indian Ocean) and its avifauna. In: Nettleship DN, Burger J, Gochfeld M (eds) Seabirds on islands. Threats, case studies and action plans, BirdLife Conservation Series no. 1, BirdLife International, Cambridge, pp 122-132 Martínez-Gómez JE, Jacobsen JK (2004) The conservation status of Townsend's Shearwater Puffinus auricularis auricularis. Biol Conserv 116:35-47

Miskelly CM, Taylor GA (2004) Establishment of a colony of Common diving Petrels (Pelecanoides urinatrix) by chick transfers and acoustic attraction. Emu 104:205-211

Mitchell PI, Newton SF (2004) European Storm-Petrel. In: Mitchell PI, Newton SF, Ratcliffe N, Dunn TE (eds) Seabird populations of Britain and Ireland, Poyser, London, pp 81-100

Morse DH, Buchheister CW (1979) Nesting patterns of Leach's Storm-Petrels on Matinicus Rock, Maine. Bird-Banding 50:145-158

Morse DH, Kress SW (1984) The effect of burrow loss on mate choice in the Leach's Storm-

Petrel. Auk 101:158-160

Mougin J-L (1991) Les paramètres contrôlant la réussite de l'incubation chez le Pétrel de Bulwer Bulweria bulwerii de l'île Selvagem Grande $\left(30^{\circ} 09^{\prime} \mathrm{N}, 15^{\circ} 52^{\prime} \mathrm{W}\right)$. Oiseau Rev Fr Ornithol 61:312323

Norman FI (1970) Ecological effects of Rabbit reduction on Rabbit Island, Wilsons Promontory, Victoria. Proc Roy Soc Victoria 83:235-252

Podolsky RE, Kress SW (1989) Factors affecting colony formation in Leach's Storm-Petrel. Auk 106:332-336

Priddel D, Carlile N (1995) An artificial nest box for burrow-nesting seabirds. Emu 95:290-294

Priddel D, Carlile N, Wheeler R (2000) Eradication of European Rabbits (Oryctolagus cuniculus) from Cabbage Tree Island, NSW, Australia, to protect the breeding habitat of Gould's Petrel (Pterodroma leucoptera leucoptera). Biol Conserv 94:115-125

Probst J-M, Le Corre M, Thébaud C (2000) Breeding habitat and conservation priorities in Pterodroma baraui, an endangered Gadfly Petrel of the Mascarene archipelago. Biol Conserv 93:135-138

Richdale LE (1963) Biology of the Sooty Shearwater Puffinus griseus. Proc Zool Soc Lond 141:1117

Rocamora G, Yeatman-Berthelot D (coord, 1999) Oiseaux menacés et à surveiller en France. Listes rouges et recherche de priorités. Populations. Tendances. Menaces. Conservation. SEOF / LPO, Paris 
Siorat F (2004) Fou de Bassan. In: Cadiou B, Pons J-M, Yésou P (eds) Oiseaux marins nicheurs de France métropolitaine (1960-2000), Éditions Biotope, Mèze, pp 70-73

Tavecchia G, Mínguez E, de León A, Louzao M, Oro D. (2008) Living close, doing differently: small-scale asynchrony in demographic parameters in two species of seabirds. Ecology 89:77-85 Thayer JA, Hester MM, Sydeman WJ (2000) Conservation biology of Rhinoceros Auklets, Cerorhinca monocerata, on Año Nuevo Island, California, 1993-1999. End Sp Update 17:63-67 Vidal E, Médail F, Tatoni T (1998) Is the Yellow-legged Gull a superabundant species in the Mediterranean? Impact on fauna and flora, conservation measures and research priorities.

Biodivers Conserv 7:1013-1026

Warham J (1990) The Petrels, their ecology and breeding systems. Academic Press, London Warham J (1996) The behaviour, population biology and physiology of the Petrels. Academic Press, London

Zino F, Oliveira P, King S, Buckle A, Biscoito M, Neves HC, Vasconcelos A (2001) Conservation of the Zino's Petrel Pterodroma madeira in the archipelago of Madeira. Oryx 35:128-136 
Table 1 Summary of the characteristic features of the four dynamic stages of the maritime grassland identified on the study islets

\begin{tabular}{|c|c|c|c|c|}
\hline Dynamic stages & Historical climax & $\begin{array}{l}\text { Biotic } \\
\text { climax }\end{array}$ & $\begin{array}{l}\text { Substitution } \\
\text { nitrophilous } \\
\text { communities }\end{array}$ & Local climax \\
\hline Vegetation type & original, primary & sub-primary & $\begin{array}{l}\text { impacted, } \\
\text { secondary }\end{array}$ & $\begin{array}{c}\text { restored, sub- } \\
\text { primary }\end{array}$ \\
\hline $\begin{array}{l}\text { Main structuring } \\
\text { species }\end{array}$ & $\begin{array}{c}\text { Festuca rubra subsp. } \\
\text { pruinosa, Daucus } \\
\text { carota subsp. } \\
\text { gummifer, Armeria } \\
\text { maritima }\end{array}$ & $\begin{array}{l}\text { Armeria } \\
\text { maritima }\end{array}$ & $\begin{array}{c}\text { Cochlearia } \\
\text { officinalis, Beta } \\
\text { vulgaris subsp. } \\
\text { maritima, } \\
\text { Atriplex } \\
\text { prostrata, } \\
\text { Matricaria } \\
\text { inodora subsp. } \\
\text { maritima }\end{array}$ & $\begin{array}{l}\text { Festuca rubra } \\
\text { subsp. pruinosa }\end{array}$ \\
\hline Species richness ${ }^{\text {a }}$ & $11.0(11.6), n=8$ & $\begin{array}{c}5.0(5.3), n \\
=3\end{array}$ & $3.0(3.6), n=16$ & $5.5(5.5), n=6$ \\
\hline $\begin{array}{l}\text { Main plant- } \\
\text { vertebrate } \\
\text { interactions }\end{array}$ & no interaction & $\begin{array}{c}\text { Rabbit } \\
\text { overgrazing }\end{array}$ & $\begin{array}{c}\text { gull and Rabbit } \\
\text { pressure }\end{array}$ & $\begin{array}{c}\text { Rabbit } \\
\text { disappearance, } \\
\text { lower gull } \\
\text { pressure }\end{array}$ \\
\hline Dynamic process & stability & sub-stability & degeneration & restoration \\
\hline Temporal scale & $1950-1970$ & $1970-1985$ & $1985-1993$ & 1993 to now \\
\hline
\end{tabular}

\footnotetext{
${ }^{a}$ Species richness expressed as median number of plant species (and mean number in brackets), $n$ $=$ number of sample plots for each stage, with a surface ranging from 3 to $100 \mathrm{~m}^{2}$ (see Methods)
} 
Fig. 1 Map of the islet of Roc'h Hir in the Molène archipelago. The main vegetated areas and rocky areas (blocks) are in white and light grey respectively and the rocky outcrop is shown in black; in dark grey the area with artificial burrows; arrows indicates the main routes of the Cormorants when they walk from their nests to the sea 
Fig. 2 Annual number of Storm Petrel AOS (with minimum, maximum and mid point in some years accounting for uncertainty; see Methods), cumulative number of dead sites (with minimum, maximum and mid point in some years accounting for uncertainty about eight sites; see Methods) and annual number of nests of Great Cormorants on Roc'h Hir since 1991 
Fig. 3 Relative frequency of annual numbers of AOS on Roc'h Hir since 1991 (a) in the different types of sites $(\mathrm{RS}=$ natural rocky sites, $\mathrm{BB}=$ burrows under blocks, $\mathrm{BS}=$ burrows in the soil, $\mathrm{AB}$ $=$ artificial burrows) and (b) in the two areas 
Fig. 4 Relative frequency of the different types of breeding sites occupied by Storm Petrels in the two areas on Roc'h Hir $(\mathrm{RS}=$ natural rocky sites, $\mathrm{BB}=$ burrows under blocks, $\mathrm{BS}=$ burrows in the soil, $\mathrm{AB}=$ artificial burrows). (a) Proportions for the total number of sites occupied at least once since $1991(n=241)$ and (b) Proportions for the number of dead sites in $2008(n=138-146)$ 
Fig. 5. Impacts of abiotic and biotic factors on Storm Petrels in the Molène archipelago colonies (from Vidal et al. 1998, modified)
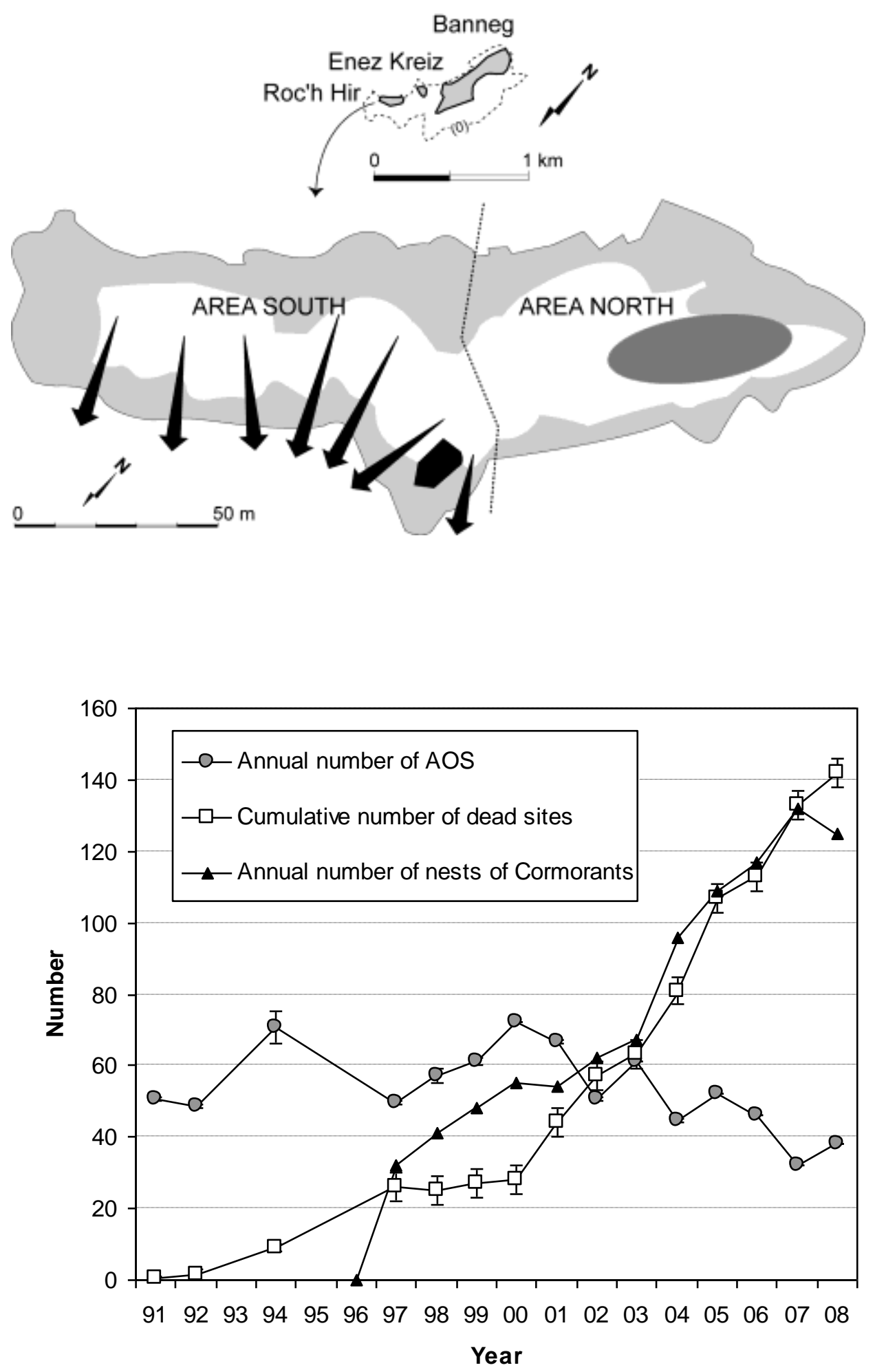


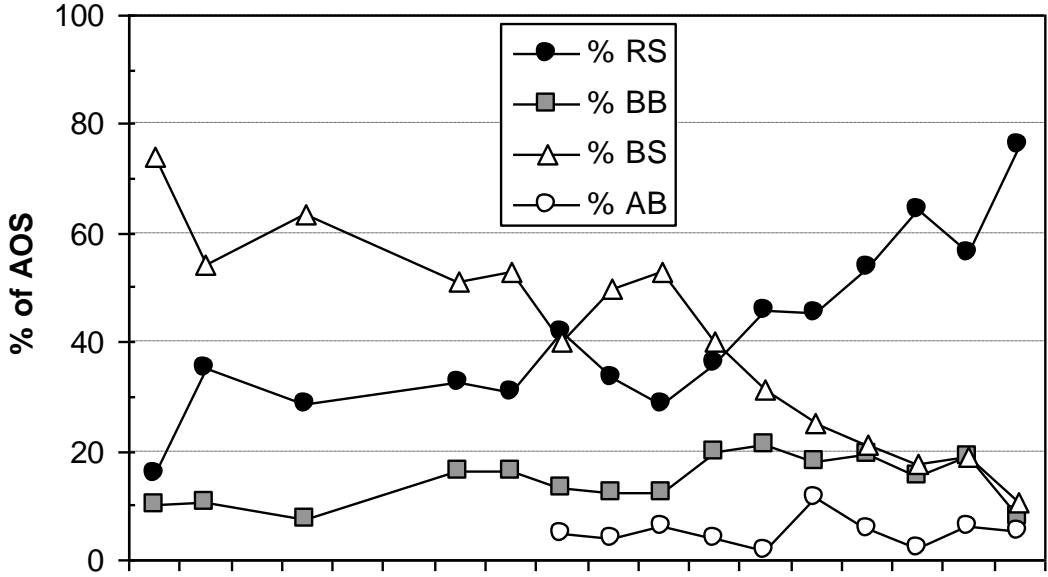

$\begin{array}{llllllllllllllllll}91 & 92 & 93 & 94 & 95 & 96 & 97 & 98 & 99 & 00 & 01 & 02 & 03 & 04 & 05 & 06 & 07 & 08\end{array}$ Year

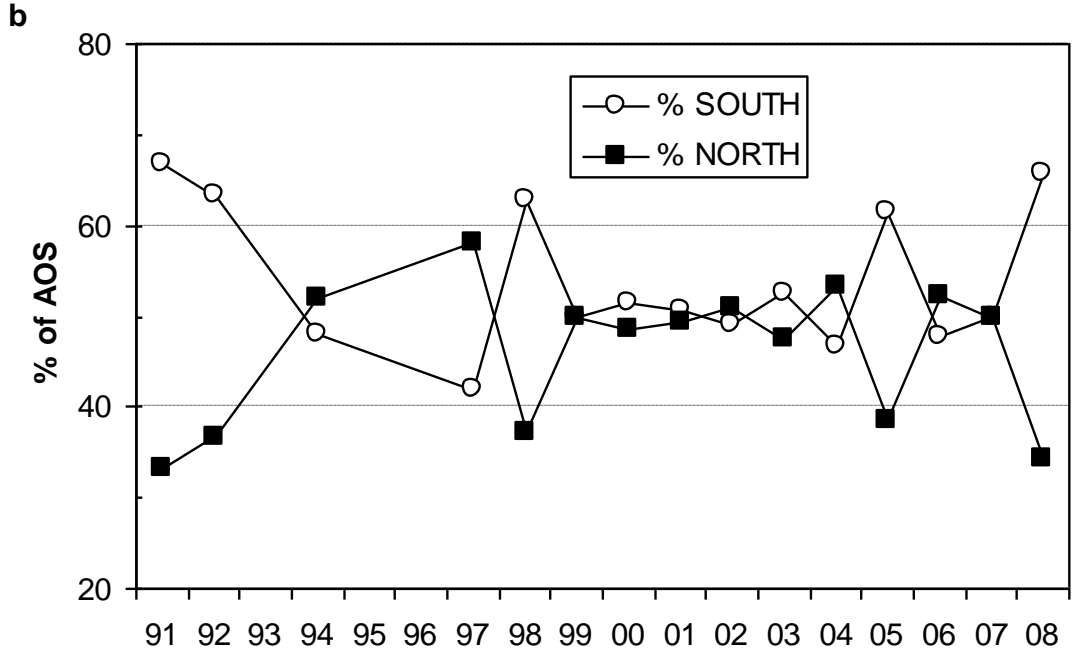

Year 


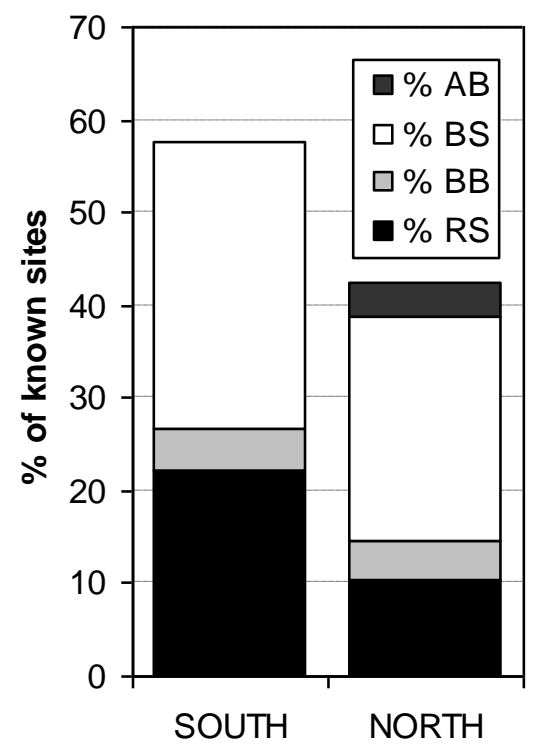

b

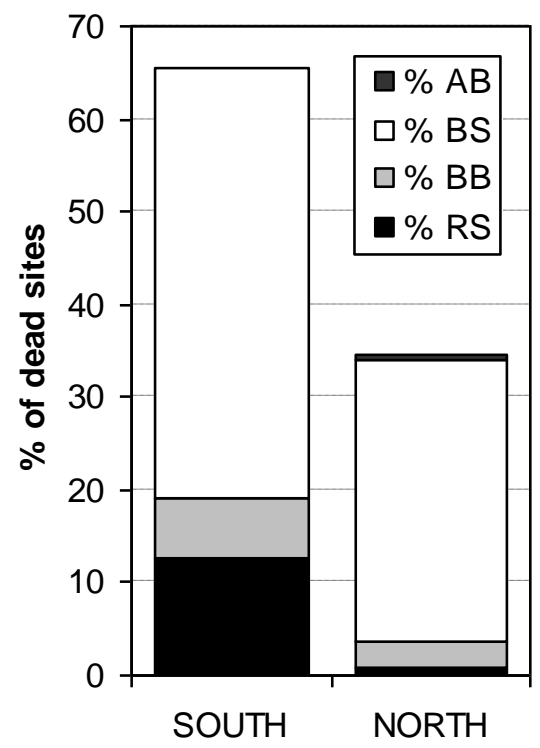

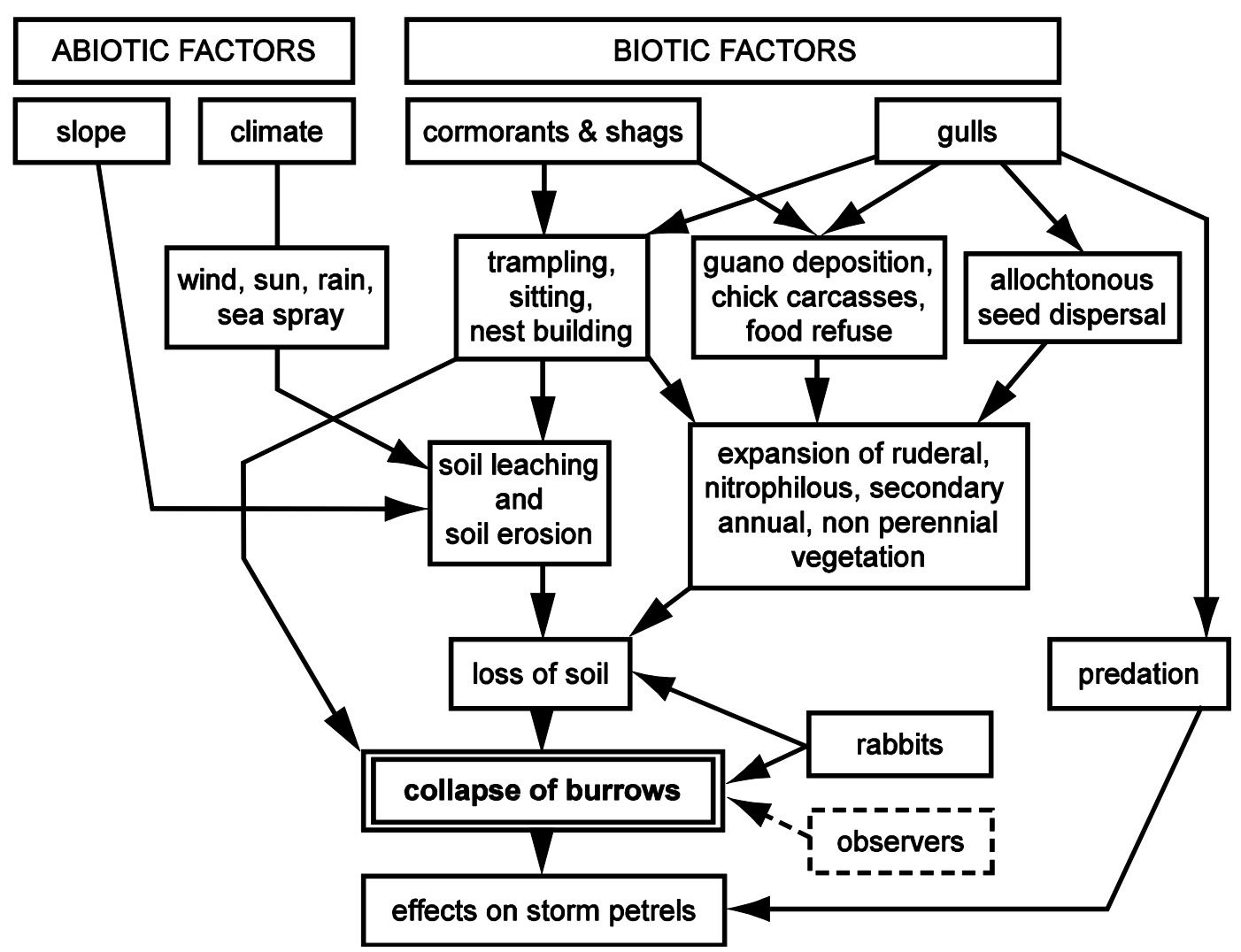

